\title{
Intersections
}

Canadian Journal of Music

Revue canadienne de musique

\section{Martin Clayton, Trevor Herbert, and Richard Middleton, eds. The Cultural Study of Music: A Critical Introduction, 2nd ed. New York: Routledge, 2012. 455 pp. ISBN 978-0-415-88191-3}

\section{Chris Tonelli}

Volume 31, numéro 2, 2011

URI : https://id.erudit.org/iderudit/1013219ar

DOI : https://doi.org/10.7202/1013219ar

Aller au sommaire du numéro

Éditeur(s)

Canadian University Music Society / Société de musique des universités canadiennes

ISSN

1911-0146 (imprimé)

1918-512X (numérique)

Découvrir la revue

Citer ce compte rendu

Tonelli, C. (2011). Compte rendu de [Martin Clayton, Trevor Herbert, and Richard Middleton, eds. The Cultural Study of Music: A Critical Introduction, 2nd ed. New York: Routledge, 2012. 455 pp. ISBN 978-0-415-88191-3]. Intersections, 31(2), 121-124. https://doi.org/10.7202/1013219ar

All Rights Reserved @ Canadian University Music Society / Société de musique des universités canadiennes, 2012
Ce document est protégé par la loi sur le droit d'auteur. L'utilisation des services d'Érudit (y compris la reproduction) est assujettie à sa politique d'utilisation que vous pouvez consulter en ligne.

https://apropos.erudit.org/fr/usagers/politique-dutilisation/ 
Ingelf's harmonic analyses serve primarily to illustrate specific new harmonic techniques operating at the surface level.

To summarize, Learn from the Masters: Classical Harmony unites selected methodologies from predecessor harmony texts-historical and current, European and North American - to present an internally consistent aural approach. Readily purchased through the publisher's Internet site, it is well worth acquiring as a specimen of music theory pedagogy in Europe today. For the soundness of its teaching method, it is worthy of consideration for course adoption by North American music departments too, particularly, but not only, those that offer courses in music arranging.

LYNN CAVANAGH

Martin Clayton, Trevor Herbert, and Richard Middleton, eds. The Cultural Study of Music: A Critical Introduction, 2nd ed. New York: Routledge, 2012. 455 pp. ISBN 978-0-415-88191-3.

The second edition of The Cultural Study of Music: A Critical Introduction substantially expands and improves upon what was already a unique and valuable contribution to the field of music studies. This is a volume devoted to helping us envision our discipline as one responsible for the study of all the meanings and functions co-produced by anything that might be conceived of as music. It advocates for and proceeds with what I have gotten into the habit of calling "total musicology." Richard Middleton, in his introduction to this edition, refers to "cultural musicology" in reference to the volume, and that can, indeed, be thought of as its slant. But I see the volume as representing more than that. Better than any other collection I've encountered, The Cultural Study of Music demonstrates a thorough attempt to understand what music-all music-is and does in the world. Ethnomusicology, popular music studies, and Western art music studies stand together in this volume; the ideas it contains present strategies for understanding any sounds the reader is to driven to become closer to through theorization. In this, it points to a music studies that is drastically different from the reality of the priorities, politics, and "cultures" of most music institutions. And that's why it's so very important; this collection and the essays contained within push our discipline to truly accept responsibility for and acknowledge the equal value of the study of all human musical practice.

The subtitle's implication that this is an "introduction" seems almost like an inside joke; the theorizations the book contains are not always generally accessible to newcomers to the field. I have frequently used essays from the first edition in my undergraduate classes, but students have found them extremely challenging. The essays assume familiarity with bodies of literature, key theorists, and difficult critical concepts; to fully understand most of the essays, students must do a good deal of supplementary research as they read. 
While the volume isn't introductory in the sense of being consistently accessible to beginners, it is in the sense that the essays each address a different large-scale theme/method in a concise manner (essays range from three to five thousand words), yet few attempt to be totalizing overviews of the topics they present. Most instead present quick exercises in denaturalization, demonstrations of how one can intervene into commonplace thinking in their area of concern. As such, they are useful in the classroom; they alert students to how easily we can fall into ideological traps, while pointing towards productive strategies they can employ to give their own writing more critical force. Of course, these essays can do the same for experienced musicologists; reading them can feel like the critical theoretical equivalent of running the drills that keep us in shape on our instruments. And, for those wanting more than a quick workout, each chapter is followed by suggestions for further reading in that topic area.

One complaint one might have had about the first edition was its lack of thematic division of its contents. It was divided into two halves, with vague and unhelpful titles: "Music and Culture" and "Issues and Debates." In the current edition, a student can open to the contents pages and learn much about key strategies of music theorization by surveying the titles of its new subdivisions: "When? Musical Histories"; "Where? Locations of Music"; "How? Processes, Practices, and Institutions of Music"; "Whose? Social Forces and Musical Belongings"; and "Who? Musical Subjectivities." The thirty-five chapters in the second edition present diverse and fundamental approaches to these five questions. Nine essays have been added, bringing to the collection work by Adam Krims, Bennett Hogg, Will Straw, Georgina Born, Jeffers Engelhardt, Ronald Radano, Fred Everett Maus, David Hesmondhalgh, and John Mowitt.

One of the nine new essays addresses the question of "where." Krims's chapter, "Music, Space, and Place: The Geography of Music," extends the concerns of his recent publication Music and Urban Geography and repeats some of its core arguments. But it also provides a concise exploration of the topic that his book does not. Here, Krims attunes the reader to ways in which the musicologies have frequently been guilty of inaccurate deployment of geographic concepts, articulating nation, for instance, with practices confined largely to local, translocal, or institutional place.

Answers to the question of "how" are provided by Hogg and Straw. Hogg's piece, "Music Technology, or Technologies of Music?" is a call for conceptual precision. He argues that a reified notion of capital $T$ Technology has often obscured our understandings of the effects and potential of particular small $t$ technologies. Further, he pushes against commonplace conceptions of the functions of certain technologies of music by pointing to the mnemic functions of musical instruments and by placing Adorno in conversation with Trevor Wishart on the topic of the effects of the phonograph. Straw's "Music and Material Culture" presents perspectives on the question of whether musical sound itself is best considered material or immaterial, provides a brief introduction to key issues in the field of mobile music studies, and ponders the material/immaterial aspects of music singles charts, file-sharing clouds, and radio playlists. 
He also points to some of less obvious ways in which materiality has affected listening practices (the aggregative effects of LP records), and to overlooked material practices (the marketing of $\mathrm{MP}_{3} \mathrm{CDs}$ in Canada and Mexico).

Born, Engelhardt, Radano, and Maus help us address "whose?" Georgina Born begins her chapter "Music and the Social" with a description of a telematic music performance linking artists in Belfast, Graz, and Hamburg, before switching abruptly to descriptions of conflict between musicians and sound engineers in recording sessions in Johannesburg. These examples work to illustrate that every instance of musicking inevitably involves multiple layers of sociality, both actual and imagined. Her examples are followed by a dense examination of key sociological and musicological approaches to music and the social, and the presentation of her own "four-plane" framework for the theorization of the layers of sociality that music engenders. Engelhardt's chapter "Music, Sound, and Religion" is an appropriate addition, given the recent rise in publications in the area. He begins by denaturalizing commonplace understandings of both music and religion. This takes the essay in several directions, including a challenge to John Blacking's definition of music as "humanly organized sound" that proposes that religious musics may be so precisely because they are experienced as not humanly organized. In "Music, Race, and the Fields of Public Culture," Radano points out that attention to music and the racial has been "largely relegated to the study of black and ethnic musics," despite the fact that "race is always among us" (309). He calls for an end to a music studies that perpetrates the notion that some musics are more racial than others. Following this, the bulk of his essay comprises a series of concentrated formulations theorizing the sources of "U.S. black music's" constitutive effect on society in the United States, Europe, and beyond. Maus's "Music, Gender, and Sexuality" is one of the few essays in the volume that offers a true introductory overview. He begins with clear and concise definitions of key terms and proceeds with a chronology of work in the area since the 1970s.

Hesmondhalgh and Mowitt take on the question "who?" In his chapter "Towards a Political Aesthetics of Music," Hesmondhalgh sets out for himself the extraordinary task of producing "a framework that would allow for the evaluation of musical institutions, processes, and developments, in terms of how music, in its various institutional, technological, and textual forms, might inhibit or promote human flourishing" (364). In the process, he provides a quick history of cultural studies' pursuit of the democratization of culture, before offering a framework that draws heavily on Martha Nussbaum's work on the ethical importance of emotions. Mowitt's chapter "Music and the Subject: Three Takes" works to remind us that there is no subjectivity without the body, that music holds the potential to destroy or transform the subject, and, via Adorno, that music can engage with levels of subjectivity other than the identificatory level.

Beyond these newly added chapters, a significant number of the authors represented in both editions have updated their contributions. Revisions are nil or minimal in the chapters by Rob Wegman, Martin Clayton, Kofi Agawu, Simon Frith, John Shepherd, Eric Clarke, and Nicola Dibben. Minor updates 
are present in the chapters by Lucy Green, Nicholas Cook, Jason Toynbee, David Clarke, David Brackett, Trevor Herbert, Gary Tomlinson, Antoine Hennion, Ian Biddle, and Dave Laing. Substantial changes have been made to the essays by Philip Bohlman, Richard Middleton, Ian Cross, Ruth Finnegan, Kevin Dawe, Lawrence Kramer, Martin Stokes, Jeff Todd Titon, and Mark Slobin: Bohlman's chapter "Music and Culture: Historiographies of Disjuncture, Ethnographies of Displacement" has been adapted so that a discussion of displacement and the increasingly racist immigration policies of France, Germany, and Arizona replaces a discussion of music's eschatological force, developed in reference to the identificatory functions of music for Nazis and for Jewish and Roma occupants of concentration camps; Middleton's "Locating the People: Music and the Popular" incorporates discussions of the Arab Spring and work by Ernst Bloch, Alain Badiou, Gayatri Spivak, and Slavoj Žižek; Finnegan's "Music, Experience, and the Anthropology of Emotion" and Slobin's "The Destiny of 'Diaspora' in Ethnomusicology" both make efforts to speak to recent developments in the field; Cross's "Music and Biocultural Evolution" increases the attention he gives to the relationship between music and language; Kramer's chapter "Subjectivity Unbound: Music, Language and Culture" formerly took the form of a polemic against those who devalued non-technical discourse about music. Interestingly, the need to challenge this position seems to have passed, leaving Kramer free to develop a new essay that presents and defends five theses on the relationship between music and language; Dawe's "The Cultural Study of Musical Instruments" broadens his purview from one predominantly concerned with traditional instruments to one that acknowledges digital music production and pushes readers to consider the full range of what might qualify as a musical instrument; Titon's “Textual Analysis or Thick Description?" has been revised to present a less totalizing view of ethnomusicology's shift from the sciences to the humanities and to advocate more overtly for applied ethnomusicology; and Stokes's "Globalization and the Politics of World Music" forwards the same powerful critiques of existing theories of cultural imperialism and hybridity, but his rewritten essay uses entirely new examples to argue his case.

Those who valued the first edition will also want to seek out the second, given the extensive expansion it offers. Those not impressed by the first may want to give the volume another chance, as many of its flaws have been corrected. And those new to this collection will likely benefit from seeking it out; it may well become a valuable new teaching tool or workout buddy.

Chris TONELLI 